\title{
Economic Social Factors And The Effect of Criminality In North Sumatera
}

\author{
Raina Linda Sari \\ Department of Economic Development \\ Universitas Sumatera Utara \\ Medan, Indonesia \\ rainabasrah@gmail.com \\ Inggrita Gusti Sari Nasution \\ Department of Economic Development \\ Universitas Sumatera Utara \\ Medan, Indonesia \\ inggritagusti@gmail.com
}

\author{
Wahyu Sugeng Imam Soeparno \\ Department of Economic Development \\ Universitas Sumatera Utara \\ Medan, Indonesia \\ ntos.wahyu@gmail.com
}

\begin{abstract}
Economic development is inseparated from the increasing needs of society in every aspects such as consumption and other needs. This condition triggered by various problems such as economic problems, social conflict, and legal awareness. Therefore, this study conducted for analyzing social economic factors such as the percentage of people who did not finish elementary school, Gini ratio, income and unemployment to criminal acts in North Sumatera. The technique of data processing used panel data regression model with The Hausman test to choose the best model within FEM or REM. The research area is all regencies/cities in North Sumatera. As the result of the study is the percentage of people who did not finish elementary school has a positive and insignificant impact to the criminal acts. This variable has the smallest coefficient value compared to the other independent variables. Gini ratio has a positive and significant impact to the criminal acts. This variable has the highest coefficient value compared to the other independent variables. Income has a negative and significant impact to the criminal acts. Unemployment Rate has a positive significant impact to the criminal acts.
\end{abstract}

Keywords - Criminal; Education; Inequality; Income; Unemployment

\section{INTRODUCTION}

Economy development is inseparated from the increasing needs of society in every aspects including the most important thing such as consumption and other needs. The more urgent needs will encourage people to take any actions with no exception even including criminal acts. This condition is triggered by various problems such as economic problems, social conflict, and legal awareness.

One crime occurred within 1 minute 32 seconds. Meanwhile, counted as many as 140 people out of 100,000 people at risk of crime [1]. The increasing of criminal acts is based on reported crimes, but the criminal acts will be greater if including with the not reported crimes.

The North Sumatera is one of the provinces in Indonesia with the high criminal acts, where according to data from BPS that North Sumatera in 2015 was the third position with the criminal acts 35,248 a year. The Metro Jaya Region (Jabodetabek and surrounding areas) as the top ranking which occurred 44,461 criminal acts and East Java was in the second place with 35,437 .

In North Sumatera, the criminal acts are dominated by the theft of motorbike with 5,543 cases in 2015. Meanwhile, the second case is narcotics with 4,249 cases in 2015 .

The criminal acts of Medan in 2017 occupies the rank 16th from 26 cities in Southeast Asia with the total value of 46.77. Meanwhile, from four cities in Indonesia, Medan is in the second position after Jakarta 52.96, Yogyakarta 43.17 and Bali 42.55. From 26 cities in Southeast Asia, Kuala Lumpur is the city with the highest criminal acts with a value of 68.64 , while the city with the lowest criminal acts is Singapore with a value of 16.64 [2].

The high criminal acts in the North Sumatera is inseparable from socio-economic conditions of the society. The level of education affects to the criminal acts [3]. The higher of people education, the higher of people morality which is the basic of human capital to prevent the increase of the criminal acts. Meanwhile, economy deceleration caused the real sector getting decrease so the people's income will be 
to reduce, those things contribute to increasing the criminal acts.

A. Problems

1. Does the percentage of people who did not finish elementary school affect the number of criminal acts in North Sumatera?

2. Does Gini Ratio affect the number of criminal acts in North Sumatera?

3. Does income per capita affect the number of criminal acts in North Sumatera?

4. Does the unemployment rates affect the number of criminal acts in North Sumatera?

B. Research Purposes

1. To know if there is any effect of the percentage of people who did not finish elementary school on criminal acts in North Sumatera.

2. To know if there is any effect of Gini Ratio on criminal acts in North Sumatera.

3. To know if there is any effect of income per capita on criminal acts in North Sumatera.

4. To know if there is any effect of unemployment Rates on criminal acts in North Sumatera.

\section{THEORY AND HYPOTHESIS}

\section{A. Criminality}

Criminality can be interpreted as a crime [4]. Criminality can also be seen from several aspects i.e.

1. From the juridical aspect, criminality is if someone violates the rules or criminal law and he is punished by the court and sentenced. However, if a person has not been punished, then the person is not considered a criminal.

2. From the social aspect, criminality is if someone fails to adjust or do deviates thing consciously/ unconsciously from the norms prevailing in society so that its actions can not be justified by the community.

3. From the economy aspect, criminality is if someone/more considered to be detrimental to others by imposing his economic interests on the surrounding community so that it is perceived an an obstacle to the happiness of others.

Criminality is any actions or acts that harm both economically and psychologically in violation of the laws prevailing in Indonesia as well as social and religious norms. Can be concluded that criminality is all kind of unlawful acts and disobey social norms so that the society opposes it [5].
There is an interrelationship between the general factors of social, political-economic and cultural building with the number of crimes in the environment both in small or large environments, including [6]:

1. Economic factors such as the system, price changes, income, unemployment, and economic inequality

2. Social factors include education, health, religion, and poverty.

3. Mental factors such as the strength of religion and influence of reading even from media.

4. Physic factors include climate conditions and others

5. Individual factors such as age, race, an influence of alcohol or even the impact of war.

\section{B. Education}

Three factors that explain the possibility of education affect the criminal participation in crime. The factors are the effect of income, the availability of time, and the patience or risk aversion [7]. Meanwhile, one of the criminal act is influenced by education factor, because education is an important factor for determining the quality of human resource [8]. Education is a resource that provides the greatest advantage over other production factors because to find a job requires skill. If the human resources are not educated, then they won't be able to enter the company to work [9].

Education will give moral influence to the participation of people in criminal activity. Where is someone who has a higher education will keep his moral not to commit criminal acts that could damage his reputation and good name, while morally, higher education will better guarantee someone to be able to work and earn a better income to provide comfort and avoid the desire to commit crimes. But this would be the opposite if someone doesn't have a high education, where he will look for ways to meet the needs of his life that can not be met with income or work earned with low level of education, so he will be tempted to commit crimes to fulfil his needs of life.

\section{Inequality of Economic}

initiation of rational criminal model activities argues that the individual decisions to be criminals or not based on benefit-cost analysis [10]. Explicitly, the individual's decision to commit crime-based on his desire to meet the targeted consumption level. If 
someone can't reach the level of consumption through legal way, there is a possibility to do so through criminal activity. The relative income of the rich when compared to the poor will make the distribution of income unequal and will increase the crime rate.

Inequality shown through Gini ratio will affect crime in many ways. The first way occurs as a result of social jealousy between the poor and the rich so that the poor will try to get what the rich have in some of forbidden ways that lead to the emergence of criminal acts. Alternatively, there may be a difference in expected income earned by the excessive gap between the income of the poor and the rich so that the poor will seek to achieve their expectation through criminal acts.

\section{Income}

Variable wage rates have a negative and significant impact on the level of criminality in Indonesia. When the salary earned too small, it will cause high crime rate in the Regency/City [11]. The minimum wage has a negative relationship to violent crime, property crime and total crime. The lower income will have an impact on the increase in violence and crime [12].

Income is a determinant factor of welfare for most people. Where a person is prosperous if he has high income, otherwise it belongs to poor categorized. On the other hand, high income also invites criminality due to the desire to earn more income than he usually gets.

\section{E. Unemployment}

Unemployment is someone who has joined in the labor force, who are actively looking for work at a certain wage level, but can't get the desired job [13]. Under the above opinion, unemployment are people whose age is in the labor force age and are looking for work [14]. High unemployment rates will increase the crimes [3].

Unemployment is directly related to the productivity of a person through it a person will get a payoff in the form of salary which will be utilized to meet various needs of his life. If the people is an unemploy it must have a low level of productivity, so to fulfil his needs he will have a difficulty. This condition will encourage someone to cover low productivity levels through various means such as crime.

\section{F. Conceptual Framework}

Criminality is any actions or acts that harm both economically and psychologically in violation of the laws prevailing in Indonesia as well as social and religious norms [5]. There is an interrelationship between the social factors and economic factors with the number of crimes in the environment both in small or large environments [6].

The level of criminality can be influenced by economic variables, demographics, or other variables either partially or simultaneously [3]. The crime rate is strongly influenced by Population Density, GDP Per Capita, Open Unemployment Rate, School Dropout Rate of Elementary (SD/MI) and Junior High (SMP/Mts), Percentage of Population with divorce status and Poor People, Gini Ratio [15].

Education plays an important role in suppressing the number of criminals which investigate crime rates based on level of education, number of police and population where only education variables affect the crime rate [16]. Population Density, Open Unemployment Rate, Average Length of School and GDP Per Capita significantly influence crime rate, while poverty level variable not affect crime level in North Sumatera 2009-2013 [17].

\section{FIGURE 1. Conceptual Frameworks}

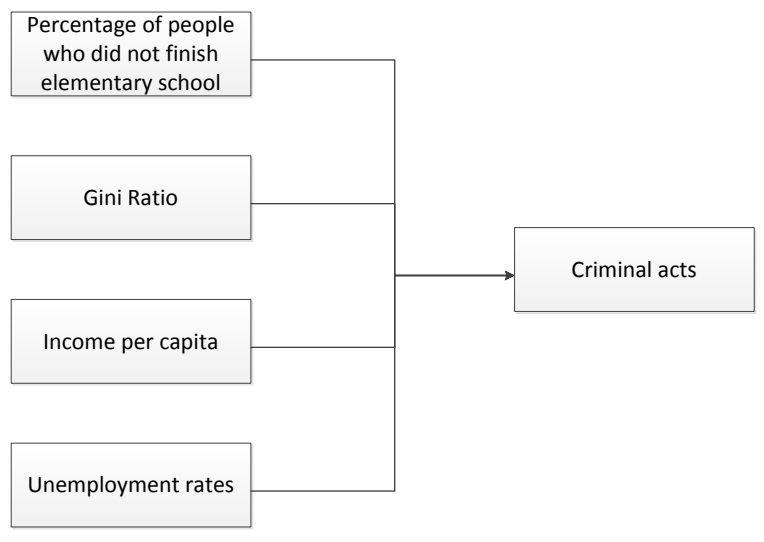

G. Hypothesis

a. Percentage of people who did not finish elementary school has a positive and significant influence to the criminal acts.

b. Gini Ratio has a positive and significant influence to the criminal acts.

c. Income Per Capita has a negative and significant influence on the criminal acts.

d. Unemployment Rate has a positive and significant influence to the criminal acts.

\section{RESEARCH METHODS}

\section{A. The Scope of Research}

This research is an associative research and used secondary data. The variables are Criminal acts as 
Dependent Variable, while Percentage of people who did not finish elementary school, Gini Ratio, Income Per Capita, and Unemployment Rate as Independent Variables. The research areas are all regencies/cities in North Sumatera which amount to 33 regencies/cities from 2013 to 2015.

\section{B. Technique of Analysis}

Data processing techniques using panel data regression. Where the processed data is a combination of cross-sections and time seriesobservations, which are obtained and researched in line with the passage of time. This panel data method has space and time dimension, so the estimation of variables and calculation results will provide wider empirical analysis.

\section{The Fixed Effect Model}

FEM is similar to a regression which uses Dummy Variable as independent variable so that can be estimated with Ordinary Least Square (OLS). With this estimate, an unbiased and consistent estimators will be generated. In fixed effect methods, individual and time characteristic differences are accommodated on the intercept so that the intercept changes between data and time.

\section{The Random Effect Model}

In random effect method differences in data and time characteristic is accommodated on the error of the model. Given there are two components that have contributed to the error formation, i.e data and time, so the random of error in REM also needs to be parsed into errors for data components, component time errors, and combined errors.

\section{E. Hausman Test}

In panel data modeling, the test can be used to see the feasibility of using paned models. This test is performed to determine whether a fixed effect method (FEM) or random effect method (REM) which can be selected. This test is based with the following hypothesis:

1. FEM is selected if the probability value is less than 0,05

2. REM is selected if the probability value is more than 0,05

\section{RESULT AND DISCUSSION}

\section{A. Results}

The Hausmann test results are as follows :

TABLE 1. Hausmann Test

\begin{tabular}{|l|l|l|l|}
\hline Test Summary & $\begin{array}{l}\text { Chi-Sq. } \\
\text { Statistic }\end{array}$ & $\begin{array}{l}\text { Chi- } \\
\text { Sq. d.f. }\end{array}$ & Prob. \\
\hline $\begin{array}{l}\text { Cross-section } \\
\text { random }\end{array}$ & 16,299729 & 4 & 0,0026 \\
\hline
\end{tabular}

Based on the Hausmann test results, the best model is fixed effect model (FEM) because the probability value of Hausmann test 0,0026 which is smaller than alpha value 0,05 .

The result of panel data regression using fixed effect model is :

TABLE 2. Panel Data Regression Fixed Effect Model (FEM)

\begin{tabular}{|l|l|l|l|l|}
\hline Variable & Coefficient & Std. Error & t-Statistic & Prob. \\
\hline C & 1375,401 & 151,4214 & 9,083267 & 0,0000 \\
\hline People_notfinish & 4,330238 & 21,57635 & 0,200694 & 0,8416 \\
\hline Gini & 2011,950 & 391,6639 & 5,136931 & 0,0000 \\
\hline Income_capita & $-0,030195$ & 0,003970 & $-7,605098$ & 0,0000 \\
\hline Unemployment & 24,78655 & 11,36952 & 2,180088 & 0,0331 \\
\hline & & & \\
\hline R-squared & 0,962374 & Mean dependent var & 2448,018 \\
\hline Adj. R-squared & 0,940527 & S.D. dependent var & 1934,936 \\
\hline S.E. of regression & 481,7136 & Sum squared resid & 14386975 \\
\hline F-statistic & 44,05013 & Durbin-Watson stat & 2,695683 \\
\hline Prob(F-statistic) & 0,000000 & \multicolumn{5}{l}{} \\
\hline
\end{tabular}

Based on the regression result, the $r$ squared value is 0.9623 indicating the level of independent variable (Percentage of people who did not finish elementary school, Gini Ratio, Income per capita and Unemployment Rate) able to explain the dependent variable (criminal acts) is $96,23 \%$ while the rest of $3,77 \%$ is the influenced of other variables that are not present in the research model.

Simultaneously, based on probability value of F-test equal to 0.0000 which is smaller than alpha value of 0.05 shows all the independent variables can affect the dependent variable together and significantly. Meanwhile, if viewed partially by comparing the probability value of t-test which is smaller than alpha value 0.05 , i.e., Gini ratio, income per capita and unemployment. Whereas percentage of people who did not finish elementary school partially did not significantly affect the criminal acts, due the children who not finishing primary school are still 
underage and under the responsibility of their parents so that if they commit an act of criminality, then the police can not take action directly or count as data in crime number. Thus, the effect of percentage of people who did not finish elementary school will affect as time goes to the crime rate in the future.

The constant coefficient value of 1375,401 shows that if all independent variables do not change (the value is constant from the previous period), then the average crime rate for all regencies/cities in North Sumatera is 1375 incidents.

For percentage of people who did not finish elementary school variable with the coefficient value of 4.33 , indicates that if the variable increase by $1 \%$, then criminal acts also increase by four incidents. For Gini ratio variable with the coefficient value of 2011,95 indicates that if the variable increase by 0.1 , then it will cause criminal acts increase by 201 incidents.

Then for income per capita variable with the coefficient value of -0.03 , indicates that if the variabel increase by 1 million Rupiah it will cause criminal acts decrease as much 30 incidents. While for unemployment rate variable with coefficient value 24.876 indicates that if the unemployment increase as much $1 \%$ it will increase the criminal acts as many 24 incidents.

TABLE 3. Coefficient Value of Fixed Effect for Each Regency/City

\begin{tabular}{|l|l|r|}
\hline No & Regency/City & \multicolumn{2}{|c|}{ Ealue of Fixed } \\
\hline 1 & Nias & $-839,40$ \\
\hline 2 & Mandailing Natal & $-1.081,91$ \\
\hline 3 & Tapanuli Selatan & $-168,35$ \\
\hline 4 & Tapanuli Tengah & $-938,47$ \\
\hline 5 & Tapanuli Utara & $-808,64$ \\
\hline 6 & Toba Samosir & $-905,79$ \\
\hline 7 & Labuhanbatu & 381,79 \\
\hline 8 & Asahan & 150,06 \\
\hline 9 & Simalungun & $-479,86$ \\
\hline 10 & Dairi & $-975,41$ \\
\hline 11 & Karo & $-523,32$ \\
\hline 12 & Deli Serdang & 964,75 \\
\hline 13 & Langkat & 696,62 \\
\hline 14 & Nias Selatan & $-887,64$ \\
\hline 15 & Humbang Hasundutan & $-799,97$ \\
\hline 16 & Pakpak Bharat & $-1.295,52$ \\
\hline 17 & Samosir & $-1.106,90$ \\
\hline 18 & Serdang Bedagai & 610,99 \\
\hline & & \\
\hline
\end{tabular}

TABLE 3. Cont.

\begin{tabular}{|l|l|r|}
\hline 19 & Batubara & 195,79 \\
\hline 20 & Padang Lawas Utara & $-695,03$ \\
\hline 21 & Padang Lawas & $-541,70$ \\
\hline 22 & Labuhanbatu Selatan & 124,53 \\
\hline 23 & Labuhanbatu Utara & $2.369,05$ \\
\hline 24 & Nias Utara & $-728,74$ \\
\hline 25 & Nias Barat & $-800,97$ \\
\hline 26 & Sibolga & $-638,65$ \\
\hline 27 & Tanjungbalai & $-634,02$ \\
\hline 28 & Pematangsiantar & $-606,41$ \\
\hline 29 & Tebing Tinggi & $-601,33$ \\
\hline 30 & Medan & $13.015,47$ \\
\hline 31 & Binjai & $-700,54$ \\
\hline 32 & Padangsidempuan & $-933,91$ \\
\hline 33 & Gunung Sitoli & $-816,57$ \\
\hline
\end{tabular}

The fixed effect coefficient value is used to see the effect of regression coefficient value of panel data for each regency/city. Medan has the largest fixed effect coefficient value which is 13.015,47. It indicates that the change of each variable gives the most impact or influence on the crime rate in Medan city. While the area that has the lowest fixed effect coefficient is Pakpak Bharat with value -1.295,52. It indicates that the change of each variable gives the least impact or influence on the crime rate in Pakpak Bharat Regency.

Based on the sign of fixed effect coefficient, there are nine regency/city that are positive value, i.e., Labuhanbatu, Asahan, Deli Serdang, Langkat, Serdang Bedagai, Batubara, Labuhanbatu Utara, Labuhanbatu Selatan and Medan. This condition illustrates that changes in the independent variables have an impact and a direct effect on the crime rate. While the other 24 regencies/cities have the negative coefficient sign, this condition has a meaning that research variables have a relatively small impact where compared to regions that have positive coefficient signs.

\section{B. Discussion}

The effect of Percentage of people who did not finish elementary school on Crime Rate

The high participation of the society to go to school will reduce their ability to commit crimes because their time will be spent mostly for school [18]. High education will bring the better and legal job, this condition tends to make someone think before doing a crime. Meanwhile, a person who only 
graduates from elementary or junior high school will have no skill and more free time so that they will have greater chance to commit crimes.

Based on the results of panel data regression that the relationship between Percentage of people who did not finish elementary school and the crime rate is positive. Therefore, this relationship is in accordance with the existing theories or studies which can be used as the basis for further analysis. Although this variable does not significantly affect to the criminal acts, it can be an early warning for the local government to overcome or reduce the percentage of people who did not finish elementary school thus reducing criminal acts. Where public education will increase and contributr to the reduction of criminal acts in each region.

\section{The Effect of Gini Ratio on Crime Rate}

There a strong relationship between income gap and crime rate through the use of Gini coefficient [19]. While assessed the relationship between income gap and crime in a region [20]. Between Gini Ratio and Crime Rate, there is a strong positive relationship [21].

Based on the results of panel data regression, the relationship between Gini ratio and the crime rate is positive. This relationship has been is accordance with the previous statements. With the largest coefficient value is compared to other variables and significantly affect the crime rate, then this variable is the main cause of high crime rate in a region. In other words, low income causes the area to tend to have high crime rate. The economic factors are the main couse of a person committing a crime (criminality) to meet the needs of his life. This condition is an important signal for government to distribute the economic growth are equally and equitable so that it can improve the welfare that ultimately reduces the crime rate.

\section{The Effect of Income per Capita on Crime Rate}

The income level is a factor that can affect the crime rate. Wage has a negative and significant impact on the crime rate in Indonesia [11]. The minimum wage rate has a negative relationship to the violence and crime [12].

Based on the result of panel data regression that the relationship between per capita income and the crime rate is negative. This relationship is in accordance with the previous statements. Although income per capita is a major part of the economic factors, the small value coefficient shows that the income per capita does not indicate the actual conditions occurring in the societies. Governments should take sustained action so that people's incomes rise in real terms that have a direct impact on reducing regional crime rates.

\section{The Effect of Unemployment Rate on Crime Rate}

The impact of unemployment is declining welfare and increasing the crime rate. When people are unemployed then they do not have income or a job, so the needs of themselves and their families are not meet, especially for the basic needs. Then to meet those needs, unemployment will achieve it in an unlawful manner that violates the law. The crime rate positively affects the unemployment rate [3].

On the results of panel data regression, the relationship of unemployment to the criminal acts is in accordance with the statement which is related positively and significantly affect the criminal acts. The problem of unemployment is a quite complicated issue to solve, but it is not impossible to overcome it. Government and society must work together to overcome the problem of unemployment by creating various jobs that have a real impact on the decline in the unemployment rate which will ultimately reduce the criminal rate in each region.

\section{V.CONCLUSIONS AND RECOMMENDATIONS}

\section{A. Conclusions}

Percentage of people who did not finish elementary school did not directly affect the criminal acts. This variable has the smallest coefficient value compared to other independent variables.

The Gini directly affects the criminal acts. This variable has the highest coefficient value compared to the other independent variables.

Increased income per capita affects decrease of the crime. increased unemployment will increase the criminal rate

\section{B. Recommendations}

Development equality must keep being done by the government to reduce the criminal acts through poverty alleviation and unemployment so that people can live prosperously and fulfil their needs of life without disturbing others.

Although education does not significantly affect the criminal acts, through educational approaches. Government can also reduce the criminal rate through the fulfilment of the need for better education so that it can become a foundation for people to get a better life. 


\section{REFERENCES}

[1] Badan Pusat Statistik (2014). Statistik Kriminal. Jakarta

[2] Numbeo.com

https://www.numbeo.com/crime/region_rankings.jsp?tit le $=2017$-mid\&region $=035$

[3] Oliver '02, Alison (2002) "The Economics of Crime:

An Analysis of Crime Rates in America," The Park

Place Economist: Vol. 10

[4] Syani, Abdul (1987). Sosiologi Kriminalitas. Bandung: Remaja Rosda Karya

[5] Kartono, Kartini (2009). Patologi Sosial. PT. Raja Grafindo Persada: Jakarta.

[6] Hurwitz, Stephen (1986). Kriminologi. Terjemahan L. Moeljatno. Jakarta: PT Bina Aksara.

[7] Machin, S., Marie, O., and Vujić, S. ( 2010 ). 'The crime reducing effect of education,' IZA Discussion Paper No. 5000.

[8] Kansil, C. S. T (1994). Pengantar Ilmu Hukum dan Tata Hukum Indonesia. Balai Pustaka: Jakarta.

[9] Irawan dan Suparmoko (2008). Ekonomika Pembangunan.Yogyakarta:BPFE.

[10] Becker, Gary S (1968),"Crime and Punishment: An Economic Approach," The Journal of Political Economy, VoL7G, No.2, The University of Chicago, USA.

[11] Hardianto, Florentinus Nugroho (2009). Analisis Faktor-Faktor yang Mempengaruhi Kriminalitas di Indonesia dari Pendekatan Ekonomi”. Bina Ekonomi Majalah Ilmiah Fakultas Unpas, Vol. 13, No. 2:28-41

[12] Crofts, T. and T. Summerfield (2006). 'The Licensing of Sex Work in Australia and New Zealand' MurdochElectronic Journal of Law 13(2): 269-87.

[13] Sukirno, Sadono. (2008). Makroekonomi Teori Pengantar. Jakarta: PT Raja Grafindo Persada.

[14] Murni, Asfia (2006). Ekonomika Makro. Bandung: PT Refika Aditama.

[15] Dona, Fitri Maria. Setiawan, Setiawan (2015). Permodelan Faktor-Fator Yang Mempengaruhi Tingkat Kriminalitas di Jawa Timur dengan Analisis Regeresi Spasial. Jurnal Sains Dan Seni, Vol 4.

[16] Astuti, Nur Widi. Atmanti, Hastarini Dwi. Analisis Tingkat Kriminalitas Di Kota Semarang Dengan Pendekatan Ekonomi Tahun 2010-2012. 2014. Ph.D. Thesis. Fakultas Ekonomika dan Bisnis.

[17] Ichsan, Pinjaka Romdhon Nur, et al. Pengaruh Faktor Sosial Ekonomi Terhadap Tingkat Kriminalitas Di
Provinsi Sumatera Utara. 2016. PhD Thesis. Universitas Airlangga.

[18] Lochner, L. ( 2004 ). 'Education, work, and crime: a human capital approach', International Economic Review, vol. 45, pp. $811-43$.

[19] Choe, Jongmook (2008). "Income Inequality and Crime in the U.S." Economic Letters. pp. 31-33.

[20] Brush, J. (2007). Does income inequality lead to more crime? A comparison of cross-sectional and time-series analyses of United States counties. Economics letters, 96(2), 264-268.

[21] Fajnzylber, Pablo and Lederman, Daniel and Loayza, Norman (2002). "Inequality and Violent Crime." Journal of Law and Economics. Vol. 45, No. 1, pp. 1-3. 